\title{
人工磯の利用評価に関する現地調査 FIELD STUDIES ON THE UTILIZATION EVALUATION OF THE MAN-MADE ROCKY COAST
}

\author{
橋中秀典 $1 \cdot$ 岩本真実 $2 \cdot$ 井上雅夫 ${ }^{3} \cdot$ 島田広昭 ${ }^{4}$ \\ 吉安勇介 ${ }^{1} \cdot$ 柴橋朋希 $^{1}$ \\ Hidenori HASHINAKA, Mami IWAMOTO, Masao INOUE, \\ Hiroaki SHIMADA, Yusuke YOSHIYASU and Tomoki SHIBAHASHI

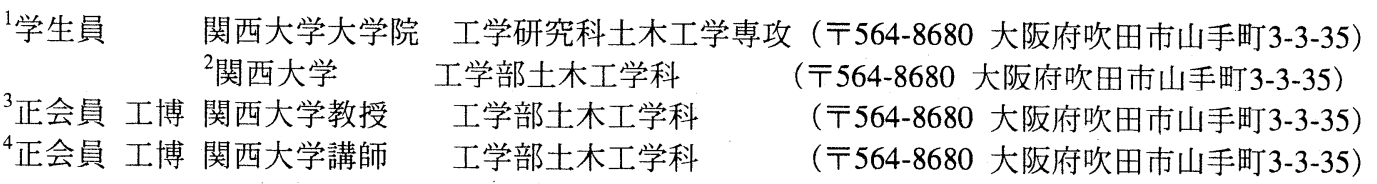

The purpose of this study is to evaluate the man-made rocky coast from user standpoint. Accordingly, questionnaire surveys are carried out for primary school children and general users in two man-made rocky coasts and natural one.

The main results obtained from the field investigations are summarized as follows. 1) The man-made rocky coast is available as the place for the environmental education. 2) The difference in level and the stone for the landscape over the height of a child should be avoided in the man-made rocky coast. 3) The tide pool with various water depth is more desirable than that with uniform depth. And, man-made tide pool should be constructed considering the various demands of the user.

Key Words: Man-made rocky coast, coast utilization, marine organism, habitat

\section{1. 緒 言}

近年，我が国の海岸整備事業においても，人工磯 が造成されるようになってきた。人工磯は，豊かな 生態系の形成が期待されるとともに，親水機能にも 優れていることから，環境教育の場としての利用も 考えられる。しかし，現在造成されている人工磯の 多くは, 防災機能を中心に計画されているため, 利用者 の安全性などについては十分に考慮されていない場合 が見受けられる.

そこで, 本研究では, 小学生を対象としては人工磯と 天然磯において, また，一般の利用者を対象としては人 工磯において，それぞれアンケート調査を行い，人工磯 の利用評価を行うとともに, その安全性に関する問題点 を明らかにしようとした。

\section{2. 調查方法}

図-1には, 調査の対象とした小学校と磯浜の位置
を示した。

小学生に関する調査は, 海岸に近い大阪府岬町立 淡輪小学校, 同多奈川小学校, 海岸からは遠い大阪 府堺市立五箇荘東小学校のいずれも4年生および引 率者を対象に行った。淡輪小学校は2000年10月26日 (木), 多奈川小学校は2001年10月15日(月)に，それ ぞれ淡輪・箱作海岸の人工磯において, 磯浜見学会 (磯遊び)を行った際に, 集合調査法によりアンケー

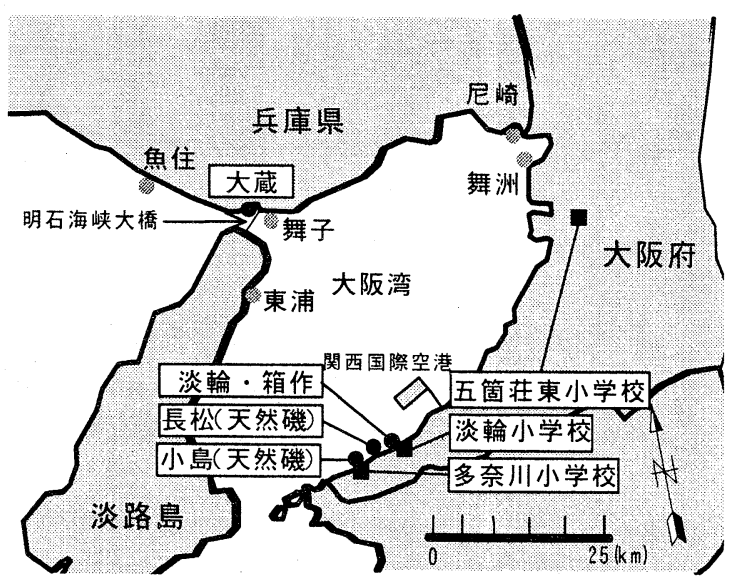

図-1 調查対象地 


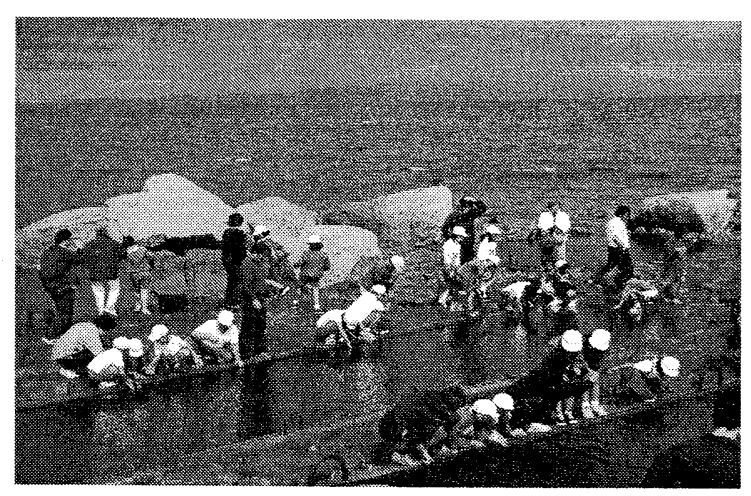

(a) 人工磯 (淡輪小学校)

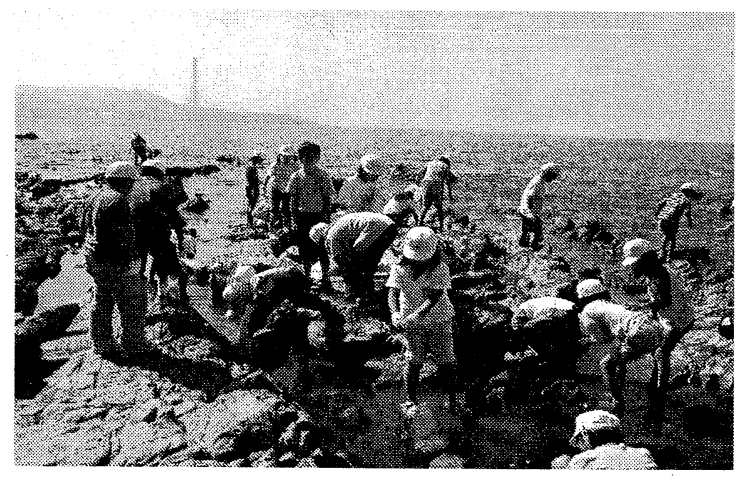

(b) 天然磯(五箇荘東小学校)

写真-1 磯遊びの様子

表-1 被験者数

\begin{tabular}{|c|c|c|c|}
\hline 学校名 & 淡輪小学校 & 多奈川小学校 & 五箇荘東小学校 \\
\hline 調查日 & $\begin{array}{c}\text { 2000年 } \\
10 \text { 月26日(木) }\end{array}$ & $\begin{array}{c}2001 \text { 年 } \\
10 \text { 月 } 15 \text { 日 (月) }\end{array}$ & $\begin{array}{c}2001 \text { 年 } \\
10 \text { 月15日(月) }\end{array}$ \\
\hline 生徒 & 91 名 & 28 名 & 81 名 \\
\hline 引率者 & 5名 & 2名 & 4名 \\
\hline 一般利用者 & 淡輪·箱作海岸 & 大蔵海岸 & \\
\hline 調査日 & $\begin{array}{c}2001 \text { 年 } \\
8 \text { 月6日 (月) } \\
\end{array}$ & $\begin{array}{c}2001 \text { 年 } \\
8 \text { 月8日 (水) }\end{array}$ & \\
\hline 被験者 & 8 名 & 22 名 & \\
\hline
\end{tabular}

卜調査を行った。また，五箇荘東小学校は，2001年 10月 15 日(月)に野外学習として, 人工磯に近い長松 海岸の天然磯で磯遊びを行っていたため, 後日，郵 便調査法によりアンケート調査を行った。写真-1(a) および(b)には，それぞれ、人工磯および天然磯で の磯遊びの様子を示した。

一般の利用者に関する調査は, 淡輪・箱作海岸の 人工磯では 2001 年 8 月 6 日(月), 大蔵海岸の人工磯で は 2001年8月8日(水)に行った。これらの調査は, 調査日の $12 \sim 15$ 時までの間に人工磯を利用した人を 対象に直接面接法によりアンケート調查を行った.

アンケート内容は, 利用者の属性のほかに, 磯浜 や磯遊びに対する評価と改善すべき問題点などとし た.なお, 表-1には, 被験者数を一括して示した。

\section{3. 小学生を対象とした調査}

\section{（1） 小学生の磯遊びの体験}

図一には，磯遊びの体験頻度を示した。これによ
・よく遊びに行くロあまり遊びに行かない ロ遊びに行ったことがない

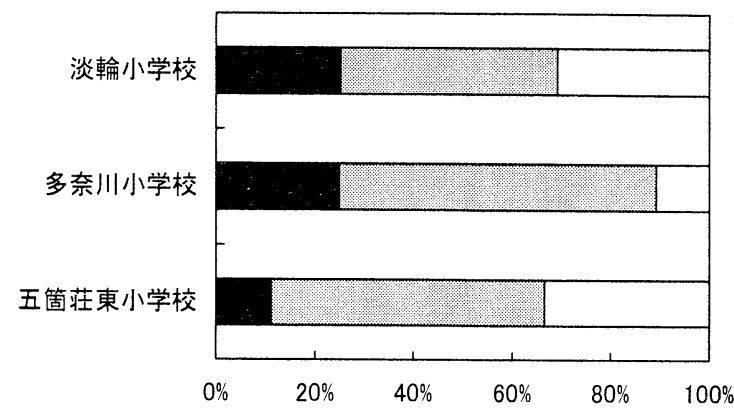

図-2 磯遊びの体験頻度

ると，「よく遊びに行く」と回答した生徒は，五箇 荘東小学校が $11 \%$ であるのに対して, 淡輪および多 奈川小学校では約 $25 \%$ でり，その割合は高くなつ ている．特に，多奈川小学校では「遊びに行ったこ

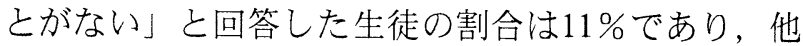
の二校に比べ，その割合が低くなっていることから 磯遊びの体験が豊富であることがわかる。これらの ことには，その周辺環境などが大きく影響している ものと考えられる。すすおち，淡輪および多奈川小 学校は海岸の近くにあり, その周辺には, 大阪府下 では比較的多くの自然環境が残されている。これに 対して, 五箇荘東小学校は, 前述の二校に比べ内陸 部にあり,その海岸線は臨海工業地帯となっている ため，磯遊びの行えるような磯浜は存在していない，

表-2には, 磯遊びを体験した場所を示した。なお， この表の (a), (b)および(c)は，それぞれ，淡輪，多 奈川および五箇荘東小学校のものである。これらに よると，磯遊びのできる磯浜が身近にある淡輪およ び多奈川小学校の生徒は，それらを気軽に利用する 傾向がみられる。一方, 磯浜が近くにない五箇荘東 小学校の生徒は, 和歌山など遠距離のところまで出

表-2 磯遊びを体験した場所

(a) 淡輪小学校

\begin{tabular}{c|c}
\hline 場 所 & 人数(人) \\
\hline 淡輪·箱作(人工磯) & 53 \\
\hline 長松(天然磯) & 16 \\
\hline マーブルビーチ(大阪府) & 1 \\
\hline 一色の浜(大阪府) & 1 \\
\hline 佐野の浜(大阪府) & 1 \\
\hline 白浜(和歌山県) & 1 \\
\hline
\end{tabular}

(b) 多奈川小学校

\begin{tabular}{c|c}
\hline 場 所 & 人数(人) \\
\hline 小島(天然磯) & 11 \\
\hline 淡輪·箱作(人工磯) & 7 \\
\hline 長松(天然磯) & 5 \\
\hline 加太(和歌山県) & 3 \\
\hline 白浜(和歌山県) & 2 \\
\hline 場所を覚えていない & 7 \\
\hline
\end{tabular}

(c) 五箇荘東小学校

\begin{tabular}{c|c}
\hline 場 所 & 入数(入) \\
\hline 和歌山(和歌山県) & 10 \\
\hline 長松(天然磯) & 6 \\
\hline 淡輪・箱作(人工磯) & 1 \\
\hline 淡路島(兵庫県) & 1 \\
\hline マーブルビーチ(大阪府) & 1 \\
\hline 場所を覚えていない & 31 \\
\hline
\end{tabular}


かけており，磯遊びが大掛かりなレジャーになって いる傾向がみられる.

\section{（2） 小学生による磯浜の評価}

図-3には，磯浜での危険に対する意識を示した。 なお，(a)，(b)および(c)図は，それぞれ，「岩石間 の空隙や段差の大きさ」，「岩表面のすべりやす さ」および「タイドプールの深さ」に関するもので ある、なお，ここでは，恐怖感があるものを危険に 感じる，また，恐怖感がないものを危険に感じない と表現する。

まず，(a)図の「岩石間の空隙や段差の大きさ」 に関して，危険に感じた生徒は，人工磯を利用した 多奈川小学校では0\%, 天然磯を利用した五箘荘東 小学校では $14 \%$ である。これは，人工磯では，磯遊 びをしたタイドプール周辺に $50 \mathrm{~cm}$ 程度の空隙が存 在しているが，その間には粒径が $10 \mathrm{~cm}$ 程度の碩が 詰まっていることや，岩が整然と積まれており段差 がほとんどないため，危険とは感じなかったものと 考えられる。しかし，天然磯では，波食棚に波食溝 が発達していることや，小さな段差の下部に礫が多 く堆積しており, 足場が悪くなっていることが危険 と評価した要因と考えられる。

次に, (b)図の「岩表面のすべりやすさ」に関し て, 危険と感じた生徒は, 人工磯を利用した多奈川
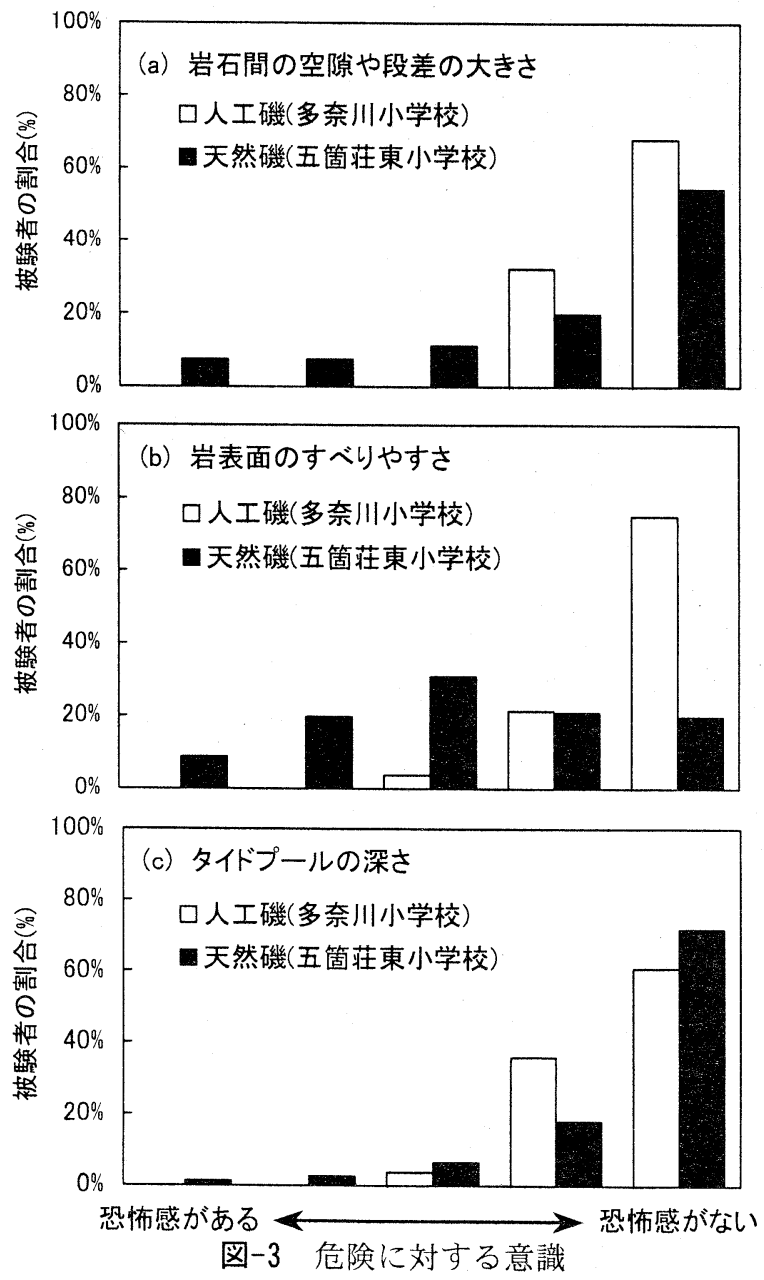

小学校では0\%, 天然磯を利用した五箇荘東小学校 では29\%である。これは，天然磯では，前述した足 場の悪さに加え, 岩表面に海藻類が多く付着してい ることが危険と評価した要因になっているものと考 えられる。

最後に, (c)図の「タイドプールの深さ」に関し て, 危険と感じた生徒は, 人工磯を利用した多奈川 小学校では0\%, 天然磯を利用した五箇荘東小学校 でも4\%である。これは，人工磯の夕イドプールの 深さが $1 \mathrm{~m}$ 程度であるが, 実際には, その中に入ら ずに周辺から「生き物観察」をしたために危険とは 感じなかったものと考えられる。また，天然磯では， 波食溝にタイドプールが形成され，潮位の変化とと もにその水深も変化し, その多くが10 20 cm程度で あり, 深い箇所でも $50 \mathrm{~cm}$ 程度である。この程度の 水深であれば, 生徒の多くは危険を感じないようで ある。

図-4には，磯浜に対する評価を示した。なお，(a) および(b)図は，それぞれ，「生き物の多さ」およ び「磯遊びの楽しさ」に関するものである.

これらによると,「生き物の多さ」に関しては, いずれの小学校でも生徒の $80 \%$ 程度が「満足」もし くは「ほぼ満足」と回答している。このことは, 人 工磯での付着動物相は, 天然磯のものに比べると, 若干劣ってはいるものの ${ }^{1,2)}$, 磯遊びを行う際の

「生き物の多さ」に関しては, 問題はないものと考 えられる。

次に，「磯遊びの楽しさ」に関しても，いずれの 小学校でも生徒の $80 \%$ 以上が「満足」もしくは「ほ ぼ満足」と回答している. 特に, 多奈川小学校では, その割合が高くなっている。これは，授業で「自然 マップ作り」をしており，その一環として磯遊びを 行ったことにより, 生徒が自然に対して非常に興味

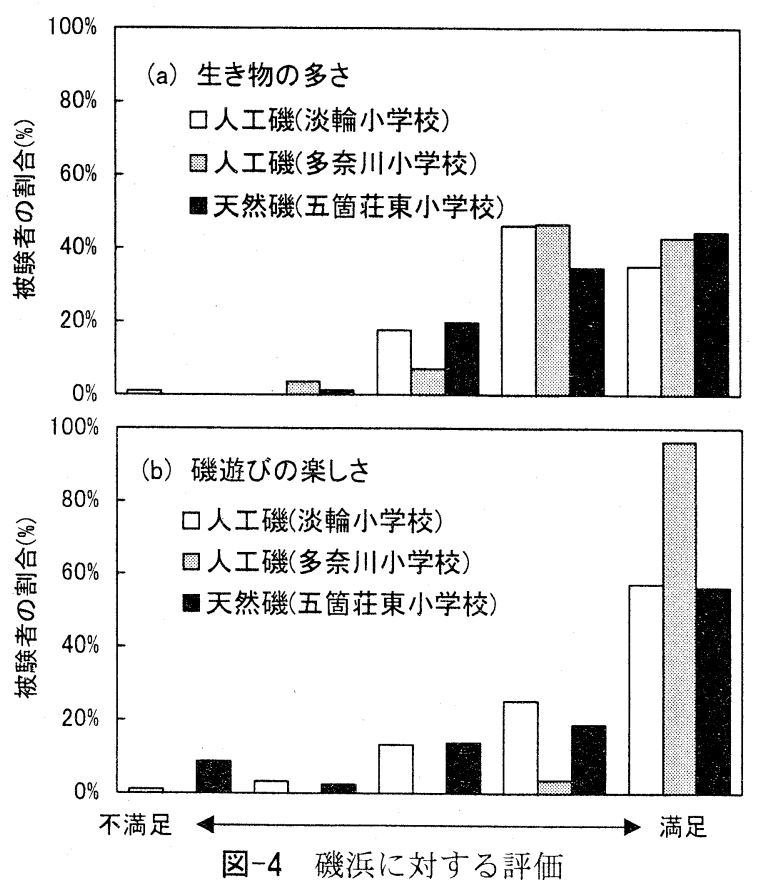


を持っていたためと考えられる。このことは, 人工 磯が磯遊びに適した場所であるとともに, 教室内で の環境教育などと複合させた体験型学習を行うこと によって，その効果が増大することを示唆している ものと言えよう。

\section{（3）引率者 (教員)による磯浜の評価}

表-3には，引率者による磯浜の評価を示した。こ れに上ると，人丁磯では，「4年生程度で引率者が 同伴すれば危険性は高くない」と回答している。し かし，「障害を持つ生徒でも安心して歩けるように 改善してほしい」,「タイドプールの水深を浅くし て，子供たちを中で遊ばせたい」および「岩の素材 や景石に注意して, 自然な感じにしてほしい」など の問題点も指摘されている。次に, 天然磯では,

「岩がすべりやすい」という回答とともに，「怪我 をして学ぶことも大切」といったものもあり, 磯浜 の危険性を強く指摘する意見はみられない。 また，

磯浜における自然体験型学習の効果を期待する回答 もみられる。

表-3 引率者 (教員)による磯浜の評価

\begin{tabular}{|c|c|}
\hline & 意 見 \\
\hline \multirow{10}{*}{$\underset{\text { 全 }}{\text { 磯 }}$} & 4年生以上であると何とか步けると思うが，引率者が少数では不安 \\
\hline & 生徒たちも気をつけて步いていたし， 少しすべるのも自然でよいと思う \\
\hline & 岩石の部分は足の不自由な生徒にとって大変 \\
\hline & 障害を持つた生徒が安心して歩けるようにしてほしい(斜面部分) \\
\hline & 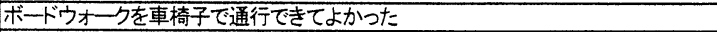 \\
\hline & タイドプールが深いので, 落ちたときに溺れないように対策をしてほしい \\
\hline & タイトプールは浅い方が生物が見やすく，安全に思う存分遊ばせてやれる気がする \\
\hline & 誰もが安心してタイドブールで遊べるよう，自由に入れるようにしたらいいと思う \\
\hline & できれば地元の砂岩を使い，自然に近く，潮の干满を利用した方がよい \\
\hline & 人工磯だから仕方ないか，もう少し自然に近い方が良い \\
\hline \multirow{5}{*}{$\begin{array}{l}\text { 天 } \\
\text { 然 }\end{array}$} & 岩がすべりやすい \\
\hline & 経験が浅いので，滑るんいうことに対する感賞がもてない \\
\hline & 履物などを用意させれば，かなり大丈夫だろう \\
\hline & 怪我をして学ぶことも大切 \\
\hline & 自然の中で遊ぶことの楽しさを経験することは，環境教育の原点だと考えている \\
\hline
\end{tabular}

\section{4.一般利用者を対象とした調査}

\section{（1）人工磯の利用目的}

図-5には，人工磯の利用目的を示した.

まず，淡輪・箱作海岸のものでは，「海水浴」が $75 \%$ で最も多く，「磯遊び」を目的とした利用者は みられなかった。これは, 現在, 一部供用が開始さ れている人工磯が淡輪海水浴場 ${ }^{3)}$ と隣接しているた めに，人工磯の利用者は，海水浴場での「海水浴」

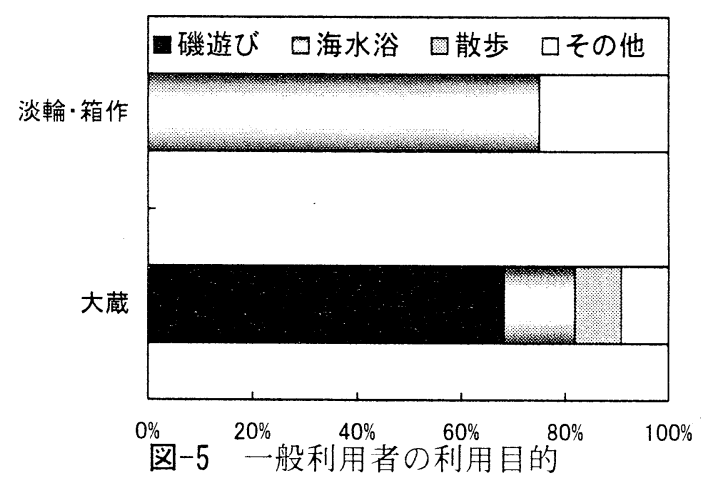

を主たる目的としており，「磯遊び」は副次的なも のと考えている。また，人工磯内の砂浜では 「ジェットスキー」の発着場もしくは休覣場として の利用もみられる。

次に，大蔵海岸のものでは，「磯遊び」が68\%で 最も多く，「海水浴」が $14 \% ， 「$ 散歩」が $9 \%$ と なっている。これは，人工磯が海水浴場と分離して 造成されているために「磯遊び」を主たる目的とし た利用者が多くなっているものと考えられる。また， 「海水浴」を目的とした利用者は, 隣接する大蔵海 水浴場のものに比べると少なく, 人工磯での海水浴 は，そこでの水深が小さいことから，保護者が子供 の安全性を考慮したうえでの利用と考えられる。

\section{（2）一般利用者による人工磯の評価}

図-6には，磯浜での危険に対する評価を示した。 なお，(a)，(b)および(c)図は，それぞれ，「岩石間 の空隙や段差の大きさ」，「岩表面のすべりやす さ」および「タイドプールの深さ」に関するもので ある。

まず，(a)図の「岩石間の空隙や段差の大きさ」 に関して, 淡輪・箱作海岸の人工磯では, 利用者の $88 \%$ 「適当」と回答しており，危険とは感じてい ないようである。また，大蔵海岸の人工磯では，利
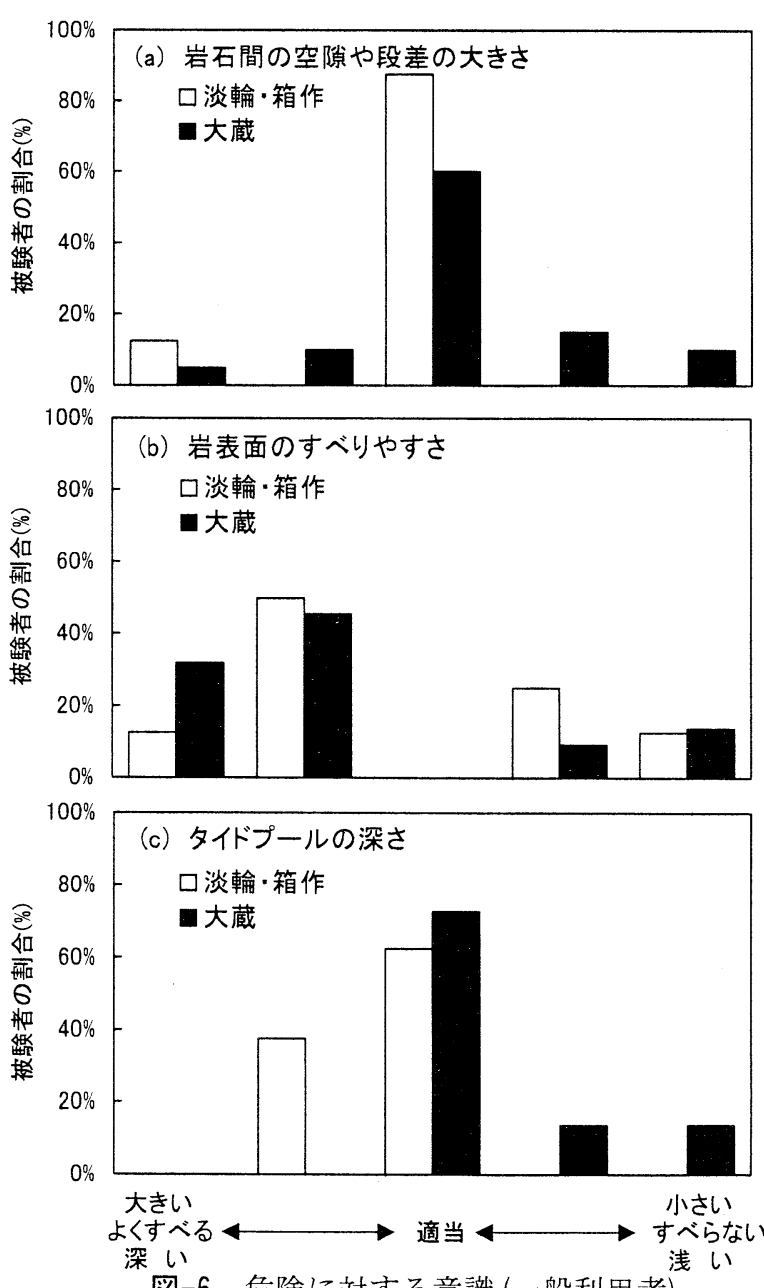

図-6 危険に対する意識 (一般利用者) 
用者の $60 \%$ 「適当」と回答しており，あまり危険 とは感じていないようである。しかし，利用者の $20 \%$ 程度が「小さい」もしくは「大きい」と回答し ているが, 前者は「空積み部分の空隙を小さくして 足を踏み入れないようにする」, 後者は「景石周辺 の空隙を人間が通れる程度の大きさにする」などの 理由によるものである.

次に, (b)図の「岩表面のすべりやすさ」に関し て, 淡輪・箱作海岸の人工磯では利用者の $63 \%$, 大 蔵海岸の人工磯では77\%が「よくすべる」もしくは

「すべる」と回答している，特に，大蔵海岸におい て，その割合が高くなっている。これは, 淡輪・箱 作海岸ではタイドプール周辺で磯遊びを行っている のに対し, 大蔵海岸ではタイドプール内で磯遊びを 行っているため, 岩表面に付着している海藻類の影 響によるものと考えられる。

最後に, (c) 図の「タイドプールの深さ」に関し $\tau$, 淡輪・箱作海岸の人工磯では利用者の $63 \%$, 大 蔵海岸の人工磯では73\%が「適当」と回答している. また, 前者では「深い」, 後者では「浅い」と回答 した利用者が一部みられる。これは，淡輪・箱作海 岸のものでは水深が1.1〜3.3mであることや, 大蔵 海岸のものではタイドプールの水深が潮位とともに 変化するために, タイドプールが空になることを考 慮して回答したためと考えられる。

図-7には, 保護者が子供の視点から判断した磯浜 の危険に対する評価を示した。なお, 図中には, 淡 輪・箱作および大藏海岸において危険であると評価 した利用者の割合を示した.

これらによると，いずれの人工磯においても， 「岩のすべりやすさ」に関しては60\%程度，「岩石 間の空隙や段差の大きさ」に関しては40\%程度の保 護者が危険であると評価している.

また，「タイドプールの深さ」に関しては，淡 輪・箱作のものでは $38 \%$, 大蔵海岸のものでは $9 \%$ の保護者が危険であると評価しており, 両者に相違 がみられる。これは, 前者のものはケーソン型タイ ドプールで水深が常に一定であること, 後者のもの は潮位とともに水深が変化することなど, 夕イド プールの形態の違いによるものと考えられる.

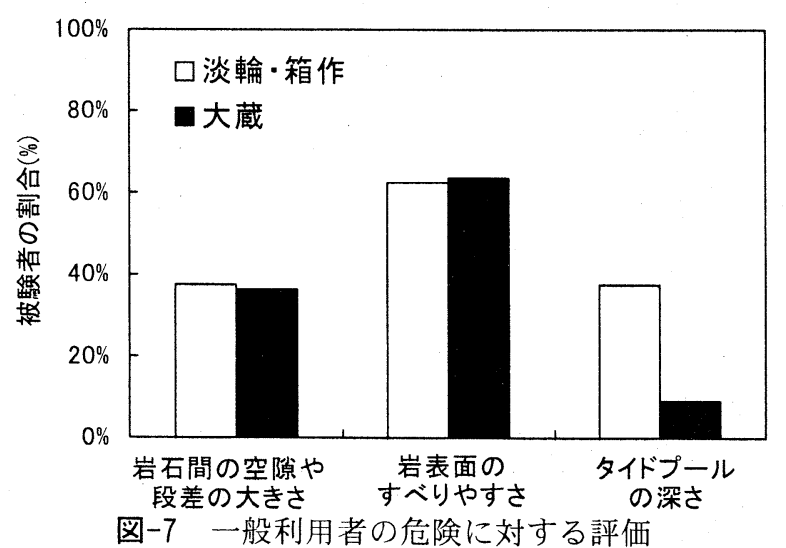

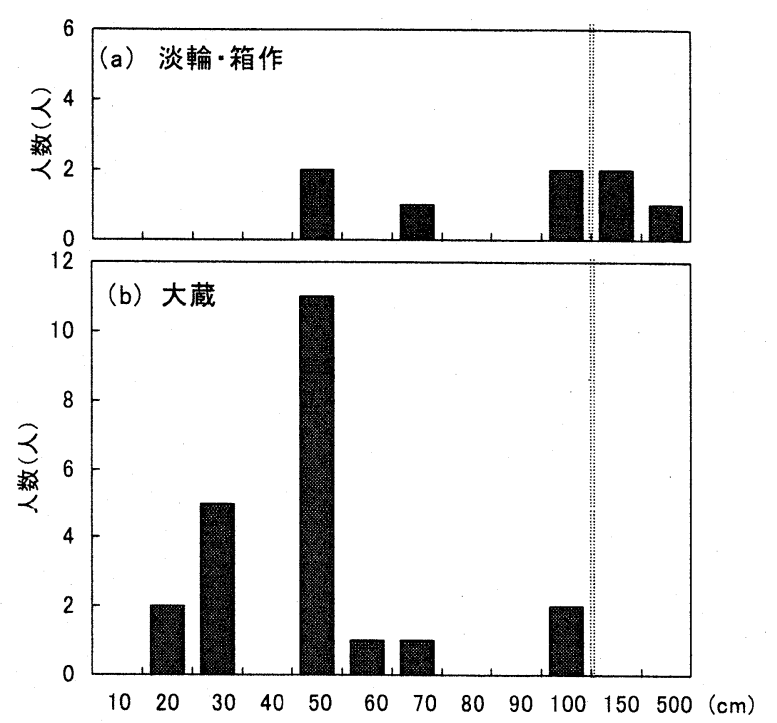

図-8 磯遊びに適したタイドプールの深さ

図-8には，磯遊びに適したタイドプールの深さを 示した。なお，(a)および(b)図は，それぞれ，淡 輪・箱作および大蔵海岸のものである.

まず，(a)図の淡輪・箱作海岸のものでは，50〜 $100 \mathrm{~cm}$ 程度と回答する利用者が多い。また， $150 \mathrm{~cm}$ や500 cmといった回答もみられるが，これらは，水 泳や素潜りなどを目的とした利用者によるものであ る. 次に, (b) 図の大蔵海岸のものでは, $20 \sim 70 \mathrm{~cm}$ 程度と回答する利用者が多く, 特に $50 \mathrm{~cm}$ が多い。

これらのことから，磯遊びに適したタイドプール の深さは，50cm以下の水深が望ましいと考えられ る. しかし，磯浜では，水泳や素潜りなどを目的と した利用者もいることから，すべてのタイドプール を同じ水深にするのではなく，利用目的に合わせた 水深を有するタイドプールを造成したり，一つのタ イドプールであっても，その中で水深を変化させた りすることが望ましい.

表-4には, 人工磯で危険と感じられる点を示した. なお，この表の(a)および(b)は，それぞれ，淡輪・ 箱作および大蔵海岸のものである.

これらによると, 淡輪・箱作海岸のものでは, 「岩のすべりやすさ」や「岩の隙間」が危険である ことを指摘している. また, 大蔵海岸のものでは,

「岩のすべりやすさ」や「岩が大きく, 多い」こと などが指摘されている。特に，「岩が大きく，多 い」や「磯が広すぎる」といったものは，「子供を 監視する際に景石によって死角ができる」ことや 「磯が広いために事故が起きたときの対処が遅机 る」などといったことを考慮したものである，なお，

表-4 危険と感じられる点

(a) 淡輪・箱作

\begin{tabular}{|c|c|}
\hline 意 見 & 人数(人) \\
\hline 岩がすべる & 3 \\
\hline 岩の隍間に入る & 2 \\
\hline 岩が不安定 & 1 \\
\hline 砂浜の中の岩 & 7 \\
\hline 保護者が必要 & 1 \\
\hline
\end{tabular}

\begin{tabular}{|c|c|}
\hline 見 & 入数 (人) \\
\hline 岩がすべる & 7 \\
\hline 岩が大きく、多い & 5 \\
\hline 磯が広すきる & 1 \\
\hline カキの殼 & 1 \\
\hline 岩の陌間が狭い & 1 \\
\hline マナーが悪い & 1 \\
\hline
\end{tabular}




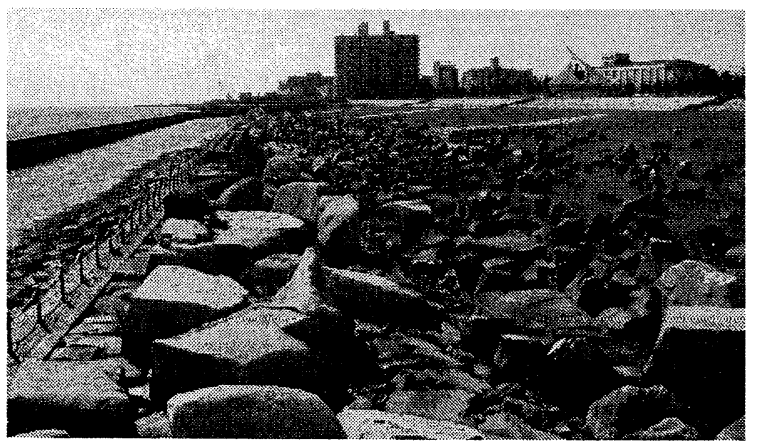

写真-2 景石の配置状況 (大蔵海岸)

表-5 改善すべき点

(a) 淡輪·箱作

\begin{tabular}{|c|c|}
\hline 意見 & 入数 (人) \\
\hline シャワー施設 & 2 \\
\hline 木陰をつくる & 2 \\
\hline 駅を近くにする & 2 \\
\hline 温泉、温水プール & 2 \\
\hline ゴミをなくす & 1 \\
\hline 女性用トイレ & 1 \\
\hline 砂浜の中の岩を取る & 1 \\
\hline 滑りにくくする & 1 \\
\hline 釣り公園 & 1 \\
\hline 砂浜を見やすく & 1 \\
\hline
\end{tabular}

\begin{tabular}{|c|c|}
\hline 意見 & 人数(人) \\
\hline 休豄所、店 & 3 \\
\hline シャワー施設 & 2 \\
\hline 木陰をつくる & 2 \\
\hline 自然が足りない & 2 \\
\hline トイレ & 2 \\
\hline 釣り公園 & 2 \\
\hline ・ゴミ箱 & 1 \\
\hline 砂を入れる & 1 \\
\hline 流れのあるタイドプール & 1 \\
\hline 背後地に遊具 & 1 \\
\hline 遊泳範囲が狭い & 1 \\
\hline 現時点で満足 & 1 \\
\hline 磯は磯たシけがいい & 1 \\
\hline (事故は親の蔶任) & 1 \\
\hline
\end{tabular}

写真-2には, 大蔵海岸の人工磯における景石の配置 状況を示した。

表-5には，人工磯の改善すべき点を示した。なお， この表の(a)および(b)は，それぞれ，淡輪・箱作お よび大蔵海岸のものである.

これらによると，淡輪・箱作海岸のものでは， 「シャワー施設」，「木陰をつくる」および「温泉， 温水プール」など，大蔵海岸のものでは，「休憩所， 店」，「シャワ一施設」，「木陰をつくる」，「自 然が足りない」，「トイレ」および「釣り公園」な ぞは複数の回答があった。また，「磯は磯だけがい い」や「事故は親の責任」といった意見も一件だけ ではあるがみられた。

\section{5. 結 語}

以上, 調査結果をまとめると次のようになる.

(1)磯遊びをよく体験している小学生は, 淡輪小 学校と多奈川小学校では約25\%であるが，五箇荘東 小学校では10\%程度である。特に後者では，約30\% の生徒が磯遊びを一度も体験していない。このこと から, 大都市近郊における人工磯の重要性が示唆さ れる。

(2)いずれの小学校の生徒についても,「生き物 の多さ」や「磯遊びの楽しさ」については, 80\%程 度もしくは，それ以上のものが満足している。 また， 引率者した教員もこのような自然体験型学習は生徒 にとって貴重な体験であると回答している。これら
のことから，人工磯における環境教育は有益なもの であると言えよう。

(3)小学生の磯浜に対する評価に関して, 人工磯 では「足場の悪さ」や「タードプールの深さ」につ いて，また，天然磯では「タイドプールの深さ」に ついてはいずれも危険とは感じていない。しかし， 岩表面に海藻類などが付着している場合，「岩のす ベりやすさ」を危険であるとしている，なお，引率 者は，人工磯については「タイドプールの深さ」， 天然磯については「岩表面のすべりやすさ」を危険 な要因としている。

(4)淡輪・箱作海岸の人工磯における一般の利用 者は，「岩のすべりやすさ」や「タイドプールの深 さ」を危険であると指摘している，また，大蔵海岸 においては，「岩のすべりやすさ」のほかに，「子 供を監視する際に景石によって死角ができる」こと も指摘している，これらのことから，岩表面の凹凸 は好ましいが, 磯浜に $1 \mathrm{~m}$ (子供の背丈)以上の段差を 設けたり，景石を配置することは避けるべきである.

(5)磯浜で生物観察をする際のタイドプールの深 さは，50cm以下のものが望ましい。しかし，磯浜 では，水泳や素潜りなどを目的とした利用者もいる ことから，すべてのタイドプールを同じ水深にする のではなく，利用目的に合わせた水深のタイドプー ルを造成したり，一つのタイドプールであっても， その中で水深を変化させたりすることが望ましい.

なお,この調査後, 大蔵海岸の人工磯に隣接した 人工砂浜で陷没事故が不幸にも発生したが，利用者 の少ない秋冬季においても海岸の維持，管理が極め て重要であることを改めて痛感した。

謝辞: 最後に, 本研究を行うにあたり, 現地調査に 協力していただいた関西大学海岸工学研究室の学生 諸君，さらには，このような機会を提供してくれた， 大阪府港湾局, 大阪府岬町立淡輪小学校, 同多奈川 小学校および堺市立五箇荘東小学校の方々に深謝す るとともに, 本研究は, 平成13年度関西大学重点領 域研究助成金によって行ったことを明記して謝意を 表する。

\section{参考文献}

1）島田広昭 - 中村克彦 - 鉄川 精 - 井上雅夫 : 磯浜海 岸の環境亡生物相に関する調査研究, 海洋開発論文 集, Vol.10, pp.129 134, 1994.

2）端谷研治 - 柴橋朋希 - 谷口正典 - 吉安勇介 - 井上雅 夫・島田広昭：人工磯における付着動物の垂直分布 に関する現地調査, 海洋開発論文集, Vol.17, pp.175 180, 2001 .

3）島田広昭・井上雅夫：海岸整備事業によって造成さ れた人工海水浴場の利用評価一淡輪海水浴場の事例 研究一, 海洋開発論文集, Vol.17, pp.445 450, 2001. 